\title{
REVIEW
}

\section{Jonathan Frankel and Ezra Mendelsohn, editors The Protestant-Jewish Conundrum (Studies in Contemporary Jewry, Vol. XXIV)}

\author{
(New York: Oxford University Press, 2010), hardcover, vii + 295 pp. \\ Reviewed by Emily D. Soloff, American Jewish Committee
}

This volume from the Institute of Contemporary Jewry at Hebrew University offers a fascinating symposium on Protestant-Jewish relations. The eight main essays include close examinations of topics such as: the issues roiling Mainline Protestant / Jewish relations in the last decade; developments in German Protestant theology; and Evangelical / Jewish efforts to rebuild the Jewish Temple in Jerusalem. The strength of the book lies in the diversity of its topics. The essays are penned by Jewish and Christian academics and have extensive footnotes pointing to additional material.

These essays are followed by additional essays and book reviews on various subjects including anti-Semitism, Zionism, and Israel and the Middle East. While the additional material is wideranging, the brevity of the symposium essays left this reviewer wanting more.

Since Presbyterian Church (USA) activity regarding Israel has had and will continue to have an impact on other Christian churches as well as on the Jewish community, "The PresbyterianJewish Impasse" by Christopher M. Leighton of the Institute for Christian \& Jewish Studies in Baltimore serves as a critical centerpiece of the book. It is essential reading for those working in the field of Jewish / Christian relations. Leighton maintains that difficulties in Presbyterian-Jewish engagement have serious political implications for the United States as Americans continue to struggle with the challenges of living in a religiously pluralist world.

He begins with an analysis of the controversy regarding the PC (USA)'s support for a Messianic Jewish congregation, which provides a backdrop for resolutions dealing with the IsraeliPalestinian conflict. He is critical of the Presbyterian embrace of both liberation theology and an exclusivist Palestinian narrative that, he believes, has led to "serious misrepresentations" and lack of "diplomatic balance" in Presbyterian overtures and documents (p. 115). Leighton understands the seductive power of Christian belief in love as the right response to end violence. He recognizes the painful challenge the Middle East poses to Isaiah's vision of a peaceable kingdom. What, Leighton asks, "are Christians to make of their own affirmations if love does not conquer all?" (p. 117).

He concludes his analysis with the $217^{\text {th }}$ General Assembly in 2006. Without deep theological study and a paradigm shift in the Church's relationship with the Jewish community, Leighton anticipates continued conflict. Otherwise, Leighton suggests, the PC (USA) will lose the opportunity to make a positive impact on the Middle East. (While he could not foresee the events of the $218^{\text {th }}$ GA in 2010, his prediction of continuing conflict over one-sided resolutions came true there as well, even though similar overtures had been rejected by previous General Assemblies.) 
Muhlenberg College Professor Peter A. Pettit's analysis in "The Passion of the Christ and Its Ramifications with Reference to the Protestant Churches and Christian-Jewish Relations" explores the influence of meta-narratives on religious responses, including not only the Mel Gibson film but other life experiences, such as the conflict between Israelis and Palestinians. Because Protestants are deeply influenced by individual narratives of Palestinian suffering and deprivation, Pettit suggests that such narrative questions as "Where does this fit in the story of your life and faith?" replace what he calls the more traditional cognitive and semiotic responses "How do you understand that?" or "What does this mean to you?" (p. 83).

Yaakov Ariel of the University of North Carolina at Chapel Hill provides a valuable historical overview in "The One and the Many: Unity and Diversity in Protestant Attitudes towards the Jews." He describes a dynamic relationship with a plurality of views. Lively exchanges have "helped both communities define their boundaries and construct their self-image." Explaining the importance of the relationship for Jews, Ariel writes, "Protestantism has exercised much influence in determining popular opinions," affecting national policies and the "civil status of Jews" (p. 16).

Susannah Heschel of Dartmouth College analyzes the tortured re-evaluation process that continues among academics and pastors in the German Protestant Church since the Shoah in "Confronting the Past: Post-1945 German Protestant Theology and the Fate of the Jews." Heschel remains pessimistic about long-term reconciliation as some in the Church urge a "turn away from Christian examination of its anti-Judaism and increasingly toward an affirmation of Christian identity" (p. 65).

In his essay, "The Attitude of the World Council of Churches (WCC) toward the IsraeliPalestinian Conflict," Haim Genizi of Bar-llan University looks at the WCC's evolution from political neutrality to criticism of Israel and political support for the rights of Palestinians. He traces the many influences on that change including: WCC's support for national liberation movements and the rights of oppressed minorities; a deep theological ambivalence about Judaism from some member churches; and the influence of Arab clergy and Christian missionaries in Arab countries.

Mark Silk of Trinity College traces the weakening of the alliance for civic causes like alleviating poverty and stopping religious discrimination between Jewish and Mainline Protestant organizations and the evolving relationship of Jews with Evangelical Christian supporters of Israel in "The Protestant Problem(s) of American Jewry." Silk suggests Jews will continue to "navigate between the Scylla of mainline hostility to Israel and the Charybdis of evangelical supersessionism" (p. 137).

Noting that "nothing remains the same for long in American religious life," Timothy P. Weber from Fuller Theological Seminary traces the rising "market-share" and political influence of Evangelical Christianity in "American Evangelicals and Israel: A Complicated Alliance" (p. 142). There is no single, monolithic Evangelical view on the rights of Palestinians and the possibility of a two-state solution, though Weber maintains that pre-millennial dispensationalist leaders and their views are more widely known than divergent views.

Motti Inbari of the University of North Carolina at Pembroke, in "'Universal Temple'? JewishChristian Collaboration in Plans to Reestablish the Holy Temple in Jerusalem," offers a quick history of Protestant millenarian beliefs. He focuses mainly on the several Jewish groups that favor Jewish sovereignty over the Temple Mount and the support they receive from Protestant fundamentalists. 
For those new to the field, Ezra Mendelsohn's introduction lays out some of the essential questions raised in the book. These include: "Is it possible to revise the old, entrenched notions of Christianity as having 'superseded' Judaism...?" and "How to resolve Christian beliefs in the superiority of their religious tradition with the need for tolerance in a new, post-Holocaust world?" (p. 5).

For those who have closely followed this series, Volume XXIV marks the end of an era with the retirement of Mendelsohn and the death of Frankel (touchingly remembered in the introduction). Mendelsohn expresses hope that the new, young Israeli-trained editors will live up to the challenge of presenting such valuable research regarding Jewish / Christian relations. 